\title{
PULMONARY FUNCTION IN MITRAL VALVULAR DISEASE: DISTRIBUTION AND DIFFUSION CHARACTERISTICS IN RESTING PATIENTS ${ }^{1}$
}

\author{
By DOUGLAS CARROLL, JEROME E. COHN, AND RICHARD L. RILEY
}

\author{
(From the Departments of Environmental Medicine and of Medicine, The Johns Hopkins \\ University and Hospital, Baltimore, Maryland)
}

(Submitted for publication October 20, 1952; accepted March 4, 1953)

Physiological investigations in patients with mitral valvular disease usually have involved, hitherto, the study of circulatory functions such as pulmonary arterial pressure, pulmonary vascular resistance, cardiac output and the changes in them brought about by exercise and following treatment. It is well known, however, that other aspects of pulmonary function are affected in patients with mitral stenosis and this paper deals with these less well-studied functions.

\section{Pathological Evidence of Lung Involvement in Disease of the Mitral Valve}

Parker and Weiss (1) were among the first to point out that in addition to pulmonary edema, morphological changes in the pulmonary vascular bed could be demonstrated post mortem in patients with mitral disease. They found changes particularly in the lower lobes : dilatation of the pulmonary capillaries with thickening of the capillary basement membrane. Larabee, Parker, and Edwards (2) described medial and intimal thickening of the pulmonary arterioles. Welch, Johnson, and Zinsser (3) described a case with obliterative vascular lesion throughout all lobes of both lungs. Other workers $(4,5)$ have confirmed the findings of Parker and Weiss.

Critical analysis of these papers raises at least three important questions: 1) are the lesions, which have been described, specific for mitral stenosis; 2) are the lesions distributed throughout the lungs in high concentration in most cases of mitral stenosis; and 3) are these lesions of functional significance? Although categorical answers cannot be given to any of these questions, at least one

\footnotetext{
1 Aided by a contract between the Office of Naval Research, Department of the Navy, and The Johns Hopkins University (NR 112-101).
}

authority believes that the first two must probably be answered at present in the negative (6). The findings to be reported in this paper bear on the third question.

\section{Physiological evidence of lung involvement in mitral disease}

It has been known for many years that increasing degrees of pulmonary engorgement and edema decrease the vital capacity and residual lung volume (7). When cardiac compensation is restored, these values return toward normal (8). Studies by cardiac catheterization have shown a low cardiac output and an increase in the pulmonary "capillary" and pulmonary arterial pressures. The resistance in the pulmonary vascular bed is also increased (9).

\section{CLINICAL MATERIAL}

Twenty-nine patients in all stages of mitral valvular disease were studied, the majority being patients in whom mitral commissurotomy was being considered. All were thought to have mitral stenosis alone with the exception of patient No. 28 who had mitral insufficiency alone and patients Nos. 9, 10, 12, 15, 17, 19, and 27 who had both mitral stenosis and insufficiency. The classification of valvular disease was based on clinical examination of the heart.

\section{METHODS}

Functional studies were designed to make a preliminary evaluation of pulmonary ventilation, circulation, distribution, and diffusion in resting patients.

Ventilation. A spirogram was obtained with the Collins Ventilometer from which the carbon dioxide absorbing mechanism had been removed, as described by Baldwin, Cournand, and Richards (10). Vital capacity and maximal breathing capacity determinations were done, and the shape of the spirographic tracing was studied for evidences of airway obstruction or other abnormality of the breathing pattern. 
Circulation. On 15 of the patients, measurements of cardiac output and pulmonary arterial pressure were made in another laboratory in this hospital.2 Pulmonary "capillary" pressure was determined in 11 patients by the method of Dexter and his coworkers (11).

Distribution. The distribution of inspired gas and mixed venous blood to alveoli in different parts of the lung was evaluated by methods first described by Lilienthal, Riley, Proemmel, and Franke, and subsequently elaborated by Riley, Cournand, Donald, and Renzetti (12-15). Estimation of the degree to which distribution was impaired was based upon comparison of the actual concentration of respiratory gases in the gas and blood leaving the lungs (expired gas and arterial blood) with the theoretical concentrations ("effective" alveolar gas and "effective" capillary blood) which would have existed if the ventilationperfusion ratio had been constant in all parts of the lung. The difference between the expired gas and the "effective" alveolar gas was used in calculating the amount of dead space gas (inspired gas) which, if added to the "effective" alveolar gas, would yield a mixture with composition identical to that of the expired gas. This amount of dead space gas was then expressed as a percentage admixture of dead space gas by taking the final step:

$$
\text { Per cent dead space admixture }=\frac{\mathrm{V}_{\mathrm{D}^{0}}}{\mathrm{~V}_{\mathrm{T}^{\circ}}} \times 100 .{ }^{3}
$$

The difference between the arterial blood and the "effective" capillary blood was used in calculating the amount of mixed venous blood which, if added to the "effective" capillary blood, would yield a mixture with composition identical to that of the arterial blood. This amount of mixed venous blood was then expressed as a percentage of venous admixture in the following manner:

$$
\text { Per cent venous admixture }=\frac{\grave{Q} \mathbf{v a}}{\mathrm{Qt}} \times 100 .^{3}
$$

The percentages of dead space admixture and venous admixture represent the form in which the degree of impairment of distribution of gas and blood throughout the lungs is expressed quantitatively.

Dead space, as the term is used here, is occupied by gas of two kinds: gas exhaled from non-perfused parts of the lungs, which therefore has not taken any part in gas exchange, and gas exhaled from relatively poorly perfused alveoli. The term dead space thus includes true dead space and a dead-space-like contribution. Venous admixture is also made up of two parts. One is contributed by blood which has passed through non-ventilated regions, such as direct pulmonary arterio-venous communications, dense fibrotic tissue and non-ventilated alveoli. Small contributions from Thebesian and anterior cardiac veins are also included if they empty into the oxygenated stream beyond the alveoli. The other part consists of blood which has passed through relatively poorly ventilated alveoli.

$2 \mathrm{We}$ are indebted to Dr. Henry Bahnson, Dr. Richard Bing, and the Surgical Physiology Laboratory for the hemodynamic studies.

3 See table of symbols.
The term venous admixture thus includes true venous admixture and a venous-admixture-like contribution. Dead space and venous admixture values cannot be subdivided into their component parts on the basis of data to be presented in this paper. Furthermore, since both terms will be used in the expanded sense just defined, the values do not necessarily correspond to those obtained by other methods.

The upper limit of normal values for the ratio of dead space to tidal volume is considered to be 0.30 and the upper limit for the ratio of venous admixture to total blood flow is considered to be 0.06 . Abnormally high values for either dead space or venous admixture ratio are interpreted as indicating abnormal variations in the ventilationperfusion ratio in different parts of the lung. In general, a high percentage of dead space indicates ventilation of areas which are poorly perfused or non-perfused, and a high percentage of venous admixture indicates perfusion of areas which are poorly ventilated or non-ventilated.

Diffusion. The diffusion characteristics of the lung were estimated by determining the diffusing capacity for oxygen, which is the amount of oxygen in ml. which would diffuse across the alveolo-capillary membrane in one minute if the oxygen partial pressure gradient was $1 \mathrm{~mm}$. $\mathrm{Hg}$. The diffusing capacity can be expressed mathematically as follows :

$$
\frac{\dot{\mathrm{VO}_{2}}}{\mathrm{P}_{\mathrm{AO}_{2}}-\overline{\mathrm{P}}_{\mathrm{cO}}} .^{3}
$$

The determination of diffusing capacity involves the same technical procedures as those required for evaluation of distribution characteristics. These will be discussed farther on in the text.

The diffusing capacity is primarily a function of the area of the diffusing surface and of the permeability of the surface per unit area. The total area of the surface depends upon the number and size of the pulmonary capillaries across whose walls gas exchange takes place. The permeability of the diffusing surface per unit area depends upon the character of the alveolo-capillary interface. Theoretical considerations suggest that, when there are wide variations in the permeability per unit area of membrane in different parts of the lung, the method may give values for diffusing capacity which are a little low (16). Such an error, if present, would tend to exaggerate the degree of abnormality in the patients with low diffusing capacity.

Resting values for diffusing capacity vary considerably in normal subjects, and only a few values, obtained by the method employed in this study, have been published (12). This is partly because the technics for determining blood gas tensions are not sufficiently accurate to permit confident interpretation of small alveolo-capillary gradients. These difficulties are reduced when patients with lowered diffusing capacity are studied, because in these instances the pressure gradients are bigger than normal and the error in the final calculation resulting from technical inaccuracies is reduced. In terms of diffusing capacity per square meter, values below nine will be considered abnormal for resting subjects. 
TABLE I*

The venous admixture ratios and diffusing capacities per square meter body surface calculated using assumed values for $S^{\circ}-S o$ of 20,30 , and 40 per cent saturationt

\begin{tabular}{|c|c|c|c|c|c|c|c|}
\hline & \multirow[b]{2}{*}{ Case No. } & \multicolumn{2}{|c|}{$S c^{\circ}-S \bar{v}=20$} & \multicolumn{2}{|c|}{$S c^{\circ}-S \bar{v}=30$} & \multicolumn{2}{|c|}{$S c^{\circ}-S \bar{v}=40$} \\
\hline & & $\frac{\dot{\mathrm{Q} v a}}{\dot{\mathrm{Q}} \mathrm{t}} \times 100$ & $\frac{\mathrm{Do}_{2}}{\mathrm{~m}^{2}}$ & $\frac{\dot{\mathrm{Q}} \mathrm{va}}{\dot{\mathrm{Q}} \mathrm{t}} \times 100$ & $\frac{\mathrm{Do}_{2}}{\mathrm{~m}^{2}}$ & $\frac{\dot{Q} \mathrm{va}}{\dot{\mathrm{Q}} \mathrm{t}} \times 100$ & $\frac{\mathrm{DO}_{2}}{\mathrm{~m}^{2}}$ \\
\hline Group 1 & $\begin{array}{l}1 \\
2 \\
3 \\
4 \\
5 \\
6 \\
7\end{array}$ & $\begin{array}{l}7 \\
4 \\
2 \\
5 \\
1 \\
1 \\
2\end{array}$ & $\begin{array}{l}\mathbf{N} \\
\mathbf{N} \\
\mathbf{N} \\
\mathbf{N} \\
\mathbf{N} \\
\mathbf{N} \\
\mathbf{N}\end{array}$ & $\begin{array}{l}5 \\
3 \\
1 \\
4 \\
1 \\
1 \\
1\end{array}$ & $\begin{array}{l}\mathbf{N} \\
\mathbf{N} \\
\mathbf{N} \\
\mathbf{N} \\
\mathbf{N} \\
\mathbf{N} \\
\mathbf{N}\end{array}$ & $\begin{array}{l}4 \\
2 \\
1 \\
3 \\
1 \\
1 \\
1\end{array}$ & $\begin{array}{l}\mathbf{N} \\
\mathbf{N} \\
\mathbf{N} \\
\mathbf{N} \\
\mathbf{N} \\
\mathbf{N} \\
\mathbf{N}\end{array}$ \\
\hline Group 2 & $\begin{array}{r}8 \\
9 \\
10 \\
11 \\
12 \\
13\end{array}$ & $\begin{array}{r}3 \\
11 \\
10 \\
8 \\
18 \\
17\end{array}$ & $\begin{array}{l}\text { N } \\
N \\
11 \\
12 \\
N \\
11\end{array}$ & $\begin{array}{r}2 \\
8 \\
7 \\
6 \\
13 \\
12\end{array}$ & $\begin{array}{l}\mathbf{N} \\
\mathbf{N} \\
\mathbf{1 0} \\
\mathbf{1 1} \\
\mathbf{N} \\
\mathbf{1 1}\end{array}$ & $\begin{array}{l}2 \\
6 \\
5 \\
4 \\
9 \\
9\end{array}$ & $\begin{array}{l}\mathbf{N} \\
\mathbf{N} \\
8 \\
9 \\
\mathbf{N} \\
9\end{array}$ \\
\hline Group 3 & $\begin{array}{r}14 \\
15 \\
16 \\
17 \\
18 \\
19\end{array}$ & $\begin{array}{r}6 \\
10 \\
6 \\
8 \\
11 \\
6\end{array}$ & $\begin{array}{l}7 \\
7 \\
9 \\
9 \\
6 \\
8\end{array}$ & $\begin{array}{l}4 \\
7 \\
5 \\
6 \\
8 \\
4\end{array}$ & $\begin{array}{l}5 \\
6 \\
8 \\
8 \\
5 \\
8\end{array}$ & $\begin{array}{l}3 \\
5 \\
3 \\
4 \\
6 \\
3\end{array}$ & $\begin{array}{l}5 \\
5 \\
7 \\
8 \\
5 \\
7\end{array}$ \\
\hline Group 4 & $\begin{array}{l}20 \\
21 \\
22 \\
23 \\
24 \\
25 \\
26 \\
27 \\
28 \\
29\end{array}$ & $\begin{array}{r}2 \\
9 \\
10 \\
20 \\
9 \\
16 \\
19 \\
15 \\
13 \\
2\end{array}$ & $\begin{array}{l}7 \\
6 \\
8 \\
6 \\
5 \\
6 \\
5 \\
8 \\
7 \\
5\end{array}$ & $\begin{array}{r}2 \\
6 \\
7 \\
13 \\
6 \\
11 \\
13 \\
10 \\
8 \\
1\end{array}$ & $\begin{array}{l}6 \\
6 \\
7 \\
6 \\
4 \\
6 \\
5 \\
6 \\
7 \\
5\end{array}$ & $\begin{array}{r}1 \\
4 \\
5 \\
10 \\
5 \\
8 \\
10 \\
8 \\
6 \\
1\end{array}$ & $\begin{array}{l}6 \\
5 \\
6 \\
5 \\
4 \\
5 \\
5 \\
6 \\
6 \\
4\end{array}$ \\
\hline
\end{tabular}

* This table gives a quantitative idea of the magnitude of errors which may be introduced when assumed values are used for mixed venous blood saturation.

$\dagger$ See table of symbols for definition of headings.

\section{TECHNICAL CONSIDERATIONS IN THE ANALYSIS OF DISTRIBUTION AND DIFFUSION}

The analysis of distribution and diffusion involved the simultaneous sampling of expired gas and arterial blood, with the patient breathing, first, room air and, then, a low oxygen gas mixture. The volume of expired gas was measured and samples of expired gas were analyzed for oxygen and carbon dioxide concentration. Arterial blood was analyzed for oxygen and carbon dioxide tension. The $\mathrm{pH}$ of the arterial blood was not determined (17). The oxygen saturation of the mixed venous blood was estimated, either on the basis of average values for arterio-venous difference found in other patients with mitral stenosis or on the basis of information gained by cardiac catheterization in the same patient within eight days of the respiratory study. The use of the estimated values for mixed venous blood saturation is justified by the following considerations: 1) The venous admixture ratio and diffusing capacity, which are the determinations whose calculation involves a value for mixed venous blood, are relatively insensitive to the exact value for mixed venous blood which is used; 2) an estimate of mixed venous blood saturation can be made which is believed to be adequate for present purposes; and 3) there are practical difficulties associated with the performance of cardiac catheterization. These three points require detailed consideration.
1) Relative insensitivity of the diffusing capacity and ve- nous admixture ratio to the value used for mixed venous blood saturation

Justification for the use of assumed values for the saturation of mixed venous blood depends in large measure upon the magnitude of the errors which would result if the assumed values were wrong. Accordingly, we have calculated all the data to be presented in this paper using values for the difference in saturation between "effective" capillary and mixed venous blood which are 10 per cent on either side of the more probable value of 30 (see below). In Table I the calculations using 20 and 40 per cent are to be compared with the values obtained when 30 per cent was used. These data provide quantitative information regarding the magnitude of the errors which may 
be introduced as a result of assuming values for mixed venous blood saturation. Errors of this order would not alter the interpretations presented below, nor would they greatly alter the classification of patients to be presented except in the case of Group 3.

\section{2) Basis for estimated values for mixed venous blood saturation}

Average values for the arterio-venous difference in oxygen saturation of patients with mitral stenosis can be judged from the experience gained by other workers who have used cardiac catheterization. Thirty-six patients with mitral stenosis were studied in another laboratory of this hospital. The mean and the median value for arteriovenous difference in oxygen saturation was 30 per cent, with a range extending from 15 to 50 per cent (18). Among 15 patients with mitral stenosis studied by Curti and Cohen, the mean saturation difference between "effective" capillary blood and mixed venous blood was 34 per cent, with a median value close to 30 per cent and a range extending from 20 to 60 per cent (19). It thus appears that a reasonable estimate of mixed venous blood oxygen saturation in patients with mitral stenosis who are being evaluated for commissurotomy can be made by subtracting 30 per cent from the oxygen saturation of the "effective" capillary blood. We have followed this practice when samples of mixed venous blood were not available.

The possibility must be considered of a change in arterio-venous difference when patients with mitral stenosis are changed from room air to low oxygen breathing. In 10 patients with mitral stenosis who were breathing 13 per cent oxygen, Bahnson (18) found an increase in the arterio-venous difference in five, no significant change in three, and a decrease in two, as compared to the values obtained on room air. Curti and Cohen (19) studying 14 patients with mitral stenosis, found extraordinary constancy of the saturation difference between "effective" capillary blood and mixed venous blood when the patients breathed first room air and then 15 per cent oxygen. We have, therefore, used the same saturation difference in estimating the oxygen saturation of the mixed venous blood when the patient breathed low oxygen, as was used when the patient breathed room air.

Fifteen of the patients reported in this paper were catheterized. In 12 of those the catheterization was performed within eight days of the respiratory studies and no apparent clinical change took place in the interval. These patients were considered to be in optimal condition for commissurotomy and in a stable state of cardiac compensation. In these patients, the estimation of mixed venous blood saturation was based on the arterio-venous difference found on catheterization. Only one patient, (number 24, first study) had respiratory studies performed during cardiac catheterization.

\section{3) Practical difficulties associated with cardiac catheterization}

One undesirable feature of cardiac catheterization is the limitation on the number of times the procedure can be repeated. For example, patient number 24 was studied 10 times from the respiratory point of view in an effort to evaluate the effects of ACTH therapy as well as commissurotomy (20). Three of these studies are shown in Tables XI, XII, XIII, and XIV. Catheterization was performed three times, after which no more suitable veins could be found.

A second consideration is the possibility that the pulmonary function of patients with mitral stenosis may change as a result of the sedation, prolonged immobilization in the supine position, infusion of fluid and psychological stress which often accompany cardiac catheterization. In 15 patients on whom Curti and Cohen (19) performed respiratory studies during catheterization, the venous admixture ratios were in general higher than ours. Because these patients were roughly comparable on the basis of clinical and hemodynamic criteria and because no technical reason seems to be implicated, it is possible that the venous admixture values may have risen as a result of subclinical pulmonary edema associated with the catheterization study. This would be consistent with the occasional development of frank pulmonary edema during catheterization which has been observed both at this hospital and elsewhere. Better evaluation of this aspect of the problem, as related specifically to patients with mitral stenosis, is planned.

These considerations are believed to justify the omission of cardiac catheterization at the time of the respiratory studies.

The effects of differences in the state of the patient during the periods of high and low oxygen breathing also require critical consideration. We shall discuss first the question of an unsteady state and then the question of a changed state during low oxygen breathing.

\section{Unsteady state during low oxygen breathing}

There is no doubt that some of the patients herein reported did not reach a completely steady state during the periods of low oxygen breathing. This is indicated by the high values of the $\mathrm{CO}_{2}$ to $\mathrm{O}_{2}$ exchange ratio $(\mathrm{R})$ and is further suggested by the low values for oxygen consumption during low oxygen breathing (21). Furthermore, there is no doubt that unsteadiness of this type causes an error in the calculated diffusing capacity. Preliminary studies in which serial samples of expired gas and arterial blood were taken at intervals during a 30 minute period of low oxygen breathing indicate that the presence of an unsteady state causes the calculated diffusing capacity to be somewhat low. After a 15 minute period on low oxygen, however, the magnitude of the error in diffusing capacity is negligible and in the case of patients with mitral stenosis, continuation of low oxygen breathing for longer periods increases the possibility of altering the pulmonary function by causing congestive changes. It is believed now that a period of 15 minutes on low oxygen, before collection of samples, usually constitutes a good compromise when evaluating diffusion at rest in patients with mitral stenosis. 
TABLE II

Physical characteristics, vital capacity, and maximal breathing capacity of patients in Group $1^{*}$

\begin{tabular}{|c|c|c|c|c|c|c|c|c|c|}
\hline & \multirow[b]{2}{*}{ Age } & \multirow[b]{2}{*}{ Sex } & \multirow[b]{2}{*}{ B.S.A. } & \multirow[b]{2}{*}{$\mathbf{P}_{\mathbf{B}}$} & \multicolumn{2}{|c|}{ Predicted values } & \multicolumn{2}{|c|}{ Measured values } & \multirow{2}{*}{$\begin{array}{c}\text { Per cent } \\
\text { predicted } \\
\text { V.C. } \\
\end{array}$} \\
\hline & & & & & V.C. & M.B.C. & V.C. & M.B.C. & \\
\hline $\begin{array}{l}\text { 1. D. D. } \\
\text { 2. T. P. } \\
\text { 3. C. J. } \\
\text { 4. R. H. } \\
\text { 5. D. B. }\end{array}$ & $\begin{array}{l}26 \\
39 \\
36 \\
21 \\
40\end{array}$ & $\begin{array}{l}\mathbf{F} \\
\mathbf{M} \\
\mathbf{F} \\
\mathbf{M}\end{array}$ & $\begin{array}{l}1.64 \\
1.77 \\
1.44 \\
1.85 \\
1.88\end{array}$ & $\begin{array}{l}758 \\
763 \\
755 \\
759 \\
761\end{array}$ & $\begin{array}{l}3,080 \\
3,950 \\
2,740 \\
4,400\end{array}$ & $\begin{array}{r}97 \\
117 \\
84 \\
140\end{array}$ & $\begin{array}{l}3,330 \\
3,930 \\
2,520 \\
4,410\end{array}$ & $\begin{array}{r}97 \\
135 \\
98 \\
173\end{array}$ & $\begin{array}{r}108 \\
99 \\
92 \\
100\end{array}$ \\
\hline $\begin{array}{l}\text { 6. R.R. } \\
\text { 7. V. B. }\end{array}$ & 31 & F & $\begin{array}{l}1.57 \\
1.48\end{array}$ & $\begin{array}{l}753 \\
758\end{array}$ & $\begin{array}{l}3,548 \\
2,840\end{array}$ & $\begin{array}{l}88 \\
87\end{array}$ & $\begin{array}{l}3,100 \\
3,240\end{array}$ & $\begin{array}{r}70 \\
130\end{array}$ & $\begin{array}{r}87 \\
114\end{array}$ \\
\hline
\end{tabular}

* B.S.A. = body surface area.

V.C. = vital capacity.

M.B.C. = maximal breathing capacity.

$\mathrm{P}_{\mathrm{B}}=$ barometric pressure, in $\mathrm{mm}$. $\mathrm{Hg}$.

The period actually used in the studies reported in this paper varied from nine and one-half to 15 minutes. Although the shorter periods may have led to inaccuracies in the calculated diffusing capacities, there are reasons, to be presented below, for believing that the interpretation of the data has not been materially affected.

\section{Changed state during low oxygen breathing}

The possibility that during low oxygen breathing the state of the patient may be different from that during air breathing deserves consideration. It has been demonstrated, for example, that severe degrees of hypoxia may cause an increase in cardiac output in patients with chronic pulmonary disease (22). The evidence presented in the preceding section however (Basis for estimated values for mixed venous blood saturation, paragraph 2) suggests that the arterio-venous difference in oxygen saturation remains relatively constant in patients with mitral stenosis. This finding does not in itself prove that no change in state occurs when patients with mitral stenosis are permitted to breathe a low oxygen mixture, but it suggests that the cardiac output does not change greatly.

The possibility of a minor change in state raises questions related to the technic of analyzing the alveolar-arterial tension gradient at two levels of oxygenation. As recently described (14), the assumption was made that the mean alveolo-capillary oxygen gradient and the venous admixture ratio remain constant at the two levels of oxygenation. If a minor change in state occurs, there may be small changes in the mean gradient and in the venous admixture ratio. The question under consideration is, therefore, do such changes seriously interfere with the system of analysis.

In most of the studies to be reported, the alveolar $\mathrm{Po}_{\mathrm{O}}$ during room air breathing was $100 \mathrm{~mm}$. $\mathrm{Hg}$ or higher, and the diffusion gradient at this level was less than $1 \mathrm{~mm}$.

TABLE III

Ventilatory data and arterial blood tensions of patients in Group $1^{*}$

\begin{tabular}{|c|c|c|c|c|c|c|c|c|c|c|c|}
\hline & $\mathrm{Proz}_{2}$ & $\mathrm{P}^{\mathbf{A A O}_{2}}$ & $\mathrm{PaO}_{2}$ & $\mathrm{PaCO}_{2}$ & $\mathrm{PecO}_{2}$ & $\dot{\mathbf{V}}_{\mathbf{E}}$ & $\mathrm{f}$ & $V_{D^{\text {app. }}}$ & $\dot{\mathrm{V}}_{2}$ & $\mathbf{R}$ & $\mathrm{T}$ \\
\hline 1. D. D. & $\begin{array}{r}149 \\
83\end{array}$ & $\begin{array}{r}115 \\
55\end{array}$ & $\begin{array}{l}99 \\
54\end{array}$ & $\begin{array}{l}28 \\
28\end{array}$ & $\begin{array}{l}21 \\
20\end{array}$ & $\begin{array}{l}7.7 \\
7.8\end{array}$ & $\begin{array}{l}13 \\
14\end{array}$ & $\begin{array}{l}35 \\
35\end{array}$ & $\begin{array}{l}235 \\
193\end{array}$ & $\begin{array}{l}.80 \\
.95\end{array}$ & $\begin{array}{l}11 \frac{1}{2} \\
15\end{array}$ \\
\hline 2. T. P. & $\begin{array}{r}150 \\
99\end{array}$ & $\begin{array}{r}109 \\
62\end{array}$ & $\begin{array}{r}100 \\
58\end{array}$ & $\begin{array}{l}38 \\
37\end{array}$ & $\begin{array}{l}26 \\
24\end{array}$ & $\begin{array}{l}8.6 \\
9.7\end{array}$ & $\begin{array}{l}14 \\
15\end{array}$ & $\begin{array}{l}35 \\
35\end{array}$ & $\begin{array}{l}290 \\
281\end{array}$ & $\begin{array}{l}.90 \\
.98\end{array}$ & $\begin{array}{l}14 \\
15\end{array}$ \\
\hline 3. C. J. & $\begin{array}{r}148 \\
94\end{array}$ & $\begin{array}{r}106 \\
64\end{array}$ & $\begin{array}{r}102 \\
71\end{array}$ & $\begin{array}{l}35 \\
28\end{array}$ & $\begin{array}{r}14 \\
9\end{array}$ & $\begin{array}{l}6.6 \\
7.8\end{array}$ & $\begin{array}{l}15 \\
17\end{array}$ & $\begin{array}{l}55 \\
55\end{array}$ & $\begin{array}{l}200 \\
184\end{array}$ & $\begin{array}{l}.79 \\
.93\end{array}$ & $\begin{array}{l}10 \\
13\end{array}$ \\
\hline 4. R. H. & $\begin{array}{l}149 \\
100\end{array}$ & $\begin{array}{r}107 \\
59\end{array}$ & $\begin{array}{l}97 \\
57\end{array}$ & $\begin{array}{l}35 \\
35\end{array}$ & $\begin{array}{l}25 \\
27\end{array}$ & $\begin{array}{l}7.4 \\
8.0\end{array}$ & $\begin{array}{l}13 \\
15\end{array}$ & $\begin{array}{l}35 \\
35\end{array}$ & $\begin{array}{l}268 \\
285\end{array}$ & $\begin{array}{l}.80 \\
.86\end{array}$ & $=$ \\
\hline 5. D. B. & $\begin{array}{r}149 \\
84\end{array}$ & $\begin{array}{r}104 \\
45\end{array}$ & $\begin{array}{r}102 \\
42\end{array}$ & $\begin{array}{l}39 \\
37\end{array}$ & $\begin{array}{l}25 \\
22\end{array}$ & $\begin{array}{l}6.6 \\
7.4\end{array}$ & $\begin{array}{l}12 \\
13\end{array}$ & $\begin{array}{l}88 \\
88\end{array}$ & $\begin{array}{l}229 \\
203\end{array}$ & $\begin{array}{l}.83 \\
.94\end{array}$ & $=$ \\
\hline 6. R. R. & $\begin{array}{r}148 \\
98\end{array}$ & $\begin{array}{l}94 \\
53\end{array}$ & $\begin{array}{l}92 \\
50\end{array}$ & $\begin{array}{l}42 \\
43\end{array}$ & $\begin{array}{l}27 \\
25\end{array}$ & $\begin{array}{l}5.3 \\
6.3\end{array}$ & $\begin{array}{l}17 \\
17\end{array}$ & $\begin{array}{l}35 \\
35\end{array}$ & $\begin{array}{l}223 \\
187\end{array}$ & $\begin{array}{l}.74 \\
.95\end{array}$ & $\begin{array}{l}15 \\
15\end{array}$ \\
\hline 7. V. B. & $\begin{array}{r}151 \\
78\end{array}$ & $\begin{array}{r}108 \\
41\end{array}$ & $\begin{array}{r}104 \\
36\end{array}$ & $\begin{array}{l}33 \\
33\end{array}$ & $\begin{array}{l}21 \\
20\end{array}$ & $\begin{array}{l}8.6 \\
8.5\end{array}$ & $\begin{array}{l}21 \\
21\end{array}$ & $\begin{array}{l}55 \\
55\end{array}$ & $\begin{array}{l}271 \\
216\end{array}$ & $\begin{array}{l}.77 \\
.90\end{array}$ & $\begin{array}{l}10 \\
10\end{array}$ \\
\hline
\end{tabular}

* See table of symbols for definitions of headings. 
TABLE IV

Distribution, diffusion, and hemodymamic findings on patients in Group $1^{*}$

\begin{tabular}{|c|c|c|c|c|c|c|c|c|c|c|}
\hline & $V_{D^{0}}$ & $\begin{array}{c}V_{\mathbf{D}^{\circ}} / \mathrm{V}_{\mathbf{T}^{\circ}} \\
\times 100\end{array}$ & $\underset{\times 100}{\dot{Q} v a / \dot{Q} t}$ & $\mathrm{Do}_{2} / \mathrm{m}^{2} \dagger$ & $\frac{\text { Press }}{\text { PA(m) } \ddagger}$ & Cap.f & $\begin{array}{c}\text { Measured } \\
\mathrm{Sa}-\mathrm{S} \overline{\mathbf{v}}\end{array}$ & $\begin{array}{l}\text { Assumed } \\
\mathrm{Sc}^{\circ}-\mathrm{S} \overline{\mathrm{v}}\end{array}$ & C.I.t & Dyspnea \& \\
\hline 1. D. D. & $\begin{array}{l}109 \\
121\end{array}$ & $\begin{array}{l}19 \\
24\end{array}$ & 4 & $\mathbf{N}$ & 41 & & 35 & 35 & 1.60 & $+t$ \\
\hline 2. T. P. & $\begin{array}{l}147 \\
175\end{array}$ & $\begin{array}{l}26 \\
29\end{array}$ & 3 & $\mathbf{N}$ & & & & 30 & & + \\
\hline 3. C. J. & $\begin{array}{r}120 \\
95\end{array}$ & $\begin{array}{l}30 \\
22\end{array}$ & 1 & $\mathbf{N}$ & 15 & 12 & 32 & 30 & 2.12 & + \\
\hline 4. R. H. & $\begin{array}{r}117 \\
94\end{array}$ & $\begin{array}{l}23 \\
.18\end{array}$ & 4 & $\mathbf{N}$ & & & & 30 & & 0 \\
\hline 5. D. B. & $\begin{array}{l}115 \\
151\end{array}$ & $\begin{array}{l}24 \\
32\end{array}$ & 1 & $\mathrm{~N}$ & $30 \|$ & & $20 \|$ & 30 & $3.1 \|$ & 0 \\
\hline 6. R. R. & $\begin{array}{r}81 \\
100\end{array}$ & $\begin{array}{l}29 \\
29\end{array}$ & 1 & $\mathbf{N}$ & & & & 30 & & + \\
\hline 7. V. B. & $\begin{array}{r}94 \\
106\end{array}$ & $\begin{array}{l}26 \\
30\end{array}$ & 1 & $\mathbf{N}$ & & & & 30 & & 0 \\
\hline
\end{tabular}

* See table of symbols.

$\dagger$ The diffusing capacity is divided by the body surface area in order to take account, in at least an approximate manner, of the differences in body size. When the diffusion gradient at the low oxygen level was less than $6 \mathrm{~mm}$. $\mathrm{Hg}$, the diffusing capacity has been classified as normal, since small technical errors lead to large errors in the calculation under these circumstances $(25,26)$. In some of the cases in Groups 1 and 2 , an insufficient degree of induced hypoxia contributed to the smallness of the diffusion gradient.

$\ddagger \mathrm{PA}(\mathrm{m})=$ mean pulmonary artery pressure in $\mathrm{mm} . \mathrm{Hg}$,

Cap. = capillary pressure in $\mathrm{mm}$. $\mathrm{Hg}$,

C.I. = cardiac index:cardiac output in liters per minute, per square meter body surface area.

$80=$ asymptomatic; $+=$ mild dyspnea on exertion; $++=$ moderate dyspnea on exertion; $+++=$ severe dyspnea on exertion.

|| Values obtained at catheterization four months prior to respiration studies.

Hg. This insignificant diffusion gradient would have remained insignificant in spite of small changes in the mean alveolo-capillary gradient and such a change would therefore not have distorted the predominant venous admixture gradient. During low oxygen breathing the arterial $\mathrm{Po}_{\mathrm{O}}$ was usually lowered to the vicinity of $40 \mathrm{~mm}$. $\mathrm{Hg}$, where the venous admixture gradient became very small. This small gradient would have remained small in spite of minor changes in the venous admixture ratio and such a change would therefore not have appreciably affected the predominant diffusion gradient. The choice of values for "effective" capillary oxygen tension, which approximate $100 \mathrm{~mm} . \mathrm{Hg}$ at the high level and $40 \mathrm{~mm} . \mathrm{Hg}$ at the low level, makes the evaluation of venous admixture virtually independent of the evaluation of diffusion except when extreme abnormalities are involved.4 Because of this fact, technical aspects of the respective determinations are ordinarily not affected by slight changes in the state of the patient.

We thus conclude that the changes occurring during low oxygen breathing in these patients with mitral stenosis were probably small and that small changes in state in-

4 This constitutes a change from recommendations previously made as to the choice of oxygen levels (14). A more complete discussion of this matter will be published shortly (23). troduce no significant technical difficulties if the levels of oxygenation are properly chosen.

\section{RESULTS}

The patients were divided into four groups on the basis of their distribution and diffusion characteristics. The groups were as follows:

Group 1: Normal diffusion, normal distribution;

Group 2: Normal diffusion, abnormal distribution;

Group 3: Abnormal diffusion, normal distribution;

Group 4: Abnormal diffusion, abnormal distribution;

The findings were as follows:

Normal diffusion and distribution-Group 1 (Tables II, III, and IV)

Of the 29 cases studied, seven had normal respiratory function with respect to the categories studied. In one of these, no vital or maximal 
TABLE V

Physical characteristics, vital capacity, and maximal breathing capacity of patients in Group 2*

\begin{tabular}{|c|c|c|c|c|c|c|c|c|c|}
\hline & \multirow[b]{2}{*}{ Age } & \multirow[b]{2}{*}{ Sex } & \multirow[b]{2}{*}{ B.S.A. } & \multirow[b]{2}{*}{$\mathbf{P}_{\mathbf{B}}$} & \multicolumn{2}{|c|}{ Predicted values } & \multicolumn{2}{|c|}{ Measured values } & \multirow{2}{*}{$\begin{array}{c}\text { Per cent } \\
\text { predictec } \\
\text { V.C. }\end{array}$} \\
\hline & & & & & V.C. & M.B.C. & V.C. & M.B.C. & \\
\hline $\begin{array}{l}\text { 8. B. N. } \\
\text { 10. A.C. } \\
\text { 11. A. W. } \\
\text { 12. D.S. } \\
\text { 13. C. M. }\end{array}$ & $\begin{array}{l}33 \\
40 \\
46 \\
35 \\
43 \\
30\end{array}$ & $\begin{array}{l}\mathbf{F} \\
\mathbf{F} \\
\mathbf{M} \\
\mathbf{M} \\
\mathbf{M} \\
\mathbf{M}\end{array}$ & $\begin{array}{l}1.47 \\
1.51 \\
2.12 \\
1.57 \\
1.78 \\
1.58\end{array}$ & $\begin{array}{l}766 \\
762 \\
769 \\
759 \\
769 \\
754\end{array}$ & $\begin{array}{l}3,010 \\
2,880 \\
4,240 \\
4,040 \\
4,000 \\
4,200\end{array}$ & $\begin{array}{r}82 \\
79 \\
115 \\
107 \\
112 \\
125\end{array}$ & $\begin{array}{l}2,760 \\
2,520 \\
4,200 \\
3,400 \\
4,330 \\
2,964\end{array}$ & $\begin{array}{r}70 \\
60 \\
92 \\
85 \\
100 \\
103\end{array}$ & $\begin{array}{r}92 \\
88 \\
99 \\
84 \\
108 \\
71\end{array}$ \\
\hline
\end{tabular}

* See footnote to Table II for explanation of abbreviations.

TABLE VI

Ventilatory data and arterial blood tensions of patients in Group 2*

\begin{tabular}{lrrrrrrrrrrr}
\hline \hline & $\mathrm{PIO}_{2}$ & $\mathrm{P}_{\mathrm{AO}_{2}}$ & $\mathrm{PaO}_{2}$ & $\mathrm{PacO}_{2}$ & $\mathrm{PECO}_{2}$ & \multicolumn{1}{c}{$\dot{\mathrm{V}}_{\mathrm{E}}$} & $\mathrm{f}$ & $\mathrm{V}_{\mathrm{D}^{\text {app. }}}$ & $\dot{\mathrm{V}}_{2}$ & $\mathrm{R}$ & $\mathrm{T}$ \\
\hline 8. B. N. & 150 & 114 & 107 & 32 & 22 & 6.3 & 12 & 35 & 186 & .85 & 14 \\
& 96 & 60 & 60 & 32 & 21 & 5.7 & 11 & 35 & 167 & .85 & 15 \\
9. A. C. & 149 & 108 & 88 & 35 & 22 & 7.0 & 14 & 35 & 203 & .85 & 11 \\
& 99 & 56 & 54 & 36 & 20 & 7.3 & 19 & 35 & 208 & .83 & 12 \\
10. W. S. & 151 & 111 & 91 & 35 & 23 & 9.8 & 17 & 35 & 322 & .86 & 12 \\
& 82 & 50 & 42 & 31 & 21 & 10.5 & 17 & 35 & 286 & .97 & 11 \\
11. A. W. & 149 & 102 & 88 & 41 & 22 & 7.9 & 16 & 35 & 233 & .85 & 12 \\
& 99 & 58 & 48 & 38 & 19 & 10.5 & 16 & 35 & 297 & .93 & 15 \\
12. D. S. & 151 & 120 & 83 & 31 & 18 & 14.1 & 26 & 110 & 286 & 1.00 & - \\
& 102 & 55 & 48 & 39 & 18 & 9.7 & 22 & 110 & 249 & .81 & - \\
13. C. M. & 148 & 105 & 79 & 40 & 21 & 10.5 & 20 & 55 & 279 & .92 & - \\
& 85 & 53 & 42 & 31 & 16 & 13.3 & 23 & 55 & 256 & .97 & - \\
\hline
\end{tabular}

* See table of symbols for definitions of headings.

TABLE VII

Distribution, diffusion, and hemodynamic findings on patients in Group 2*

\begin{tabular}{|c|c|c|c|c|c|c|c|c|c|c|}
\hline & $V_{D^{0}}$ & $\begin{array}{c}\mathrm{V}_{\mathbf{D}^{\circ}} / \mathbf{V}_{\mathbf{T}^{\mathrm{e}}} \\
\times 100\end{array}$ & $\underset{\text { Q́va/Q்t }}{\text { ×100 }}$ & $\mathrm{Do}_{2} / \mathrm{m}^{2} \dagger$ & $\frac{\text { Press }}{\text { PA(m) }}$ & $\frac{\text { ures }}{\text { Cap.f }}$ & $\begin{array}{l}\text { Measured } \\
\text { Sa - Sv }\end{array}$ & $\begin{array}{l}\text { Assumed } \\
\mathrm{Sc}^{\circ}-\mathrm{S} \overline{\mathbf{v}}\end{array}$ & C.I. & Dyspnea 8 \\
\hline 8. B. N. & $\begin{array}{l}123 \\
133\end{array}$ & $\begin{array}{l}39 \\
36\end{array}$ & 2 & $\mathbf{N}$ & & & & 30 & & + \\
\hline 9. A. C. & $\begin{array}{l}147 \\
132\end{array}$ & $\begin{array}{l}32 \\
38\end{array}$ & 8 & $\mathrm{~N}$ & & & & 30 & & + \\
\hline 10. W. S. & $\begin{array}{l}163 \\
169\end{array}$ & $\begin{array}{l}30 \\
34\end{array}$ & 7 & 10 & & & & 30 & & + \\
\hline 11. A. W. & $\begin{array}{l}198 \\
288\end{array}$ & $\begin{array}{l}43 \\
47\end{array}$ & 6 & 11 & & & & 30 & & + \\
\hline 12. D. S. & $\begin{array}{l}124 \\
126\end{array}$ & $\begin{array}{l}28 \\
38\end{array}$ & 13 & $\mathrm{~N}$ & & & & 30 & & + \\
\hline 13. C. M. & $\begin{array}{l}195 \\
227\end{array}$ & $\begin{array}{l}41 \\
43\end{array}$ & 12 & 11 & $47 \|$ & $26 \|$ & 39 & 30 & 2.46 & + \\
\hline
\end{tabular}

* See table of symbols for definitions of headings.

See footnotes to Table IV.

II Values obtained at catheterization four months prior to respiration studies. 
breathing capacity was recorded, but in other aspects the findings were normal. In Case 6, the vital capacity and maximal breathing capacity were slightly low, but because the other findings were normal, the patient was included in this group.

Three of these patients were catheterized. Case 3 had normal mean pulmonary arterial pressure and normal "capillary" pressure. Case 5 showed moderate elevation of pulmonary arterial pressure, and Case 1 showed a more striking elevation. Clinically, all were in cardiac compensation at the time of study. Cases 1,2, and 6 had moderate dyspnea on exertion. None was thought to have mitral insufficiency.

Normal diffusing capacity with abnormal distribution-Group 2 (Tables V,VI, and VII)

There are six patients in this group. All of these had high dead space to tidal volume ratios.
Case 8 had a normal venous admixture to total flow ratio, Case 12 had a high ratio and the remaining patients showed moderate elevation. No patient in this group had normal maximal breathing capacity, although two had normal vital capacities. All these patients had moderate dyspnea on exertion. Case 9, 10, and 12 had apical murmurs suggesting mitral insufficiency in addition to mitral stenosis. Cardiac catheterization showed rather striking elevation in pulmonary arterial and "capillary" pressures in the one patient on whom these measurements were made.

Low diffusing capacity with normal distributionGroup 3 (Tables VIII, IX, and X)

Six patients had low diffusing capacities, but normal dead space to tidal volume ratios and normal venous admixture to total blood flow ratios. Vital capacity was measured in five cases and was within normal limits in four. Maximal breathing

TABLE VIII

Physical characteristics, vital capacity, and maximal breathing capacity of patients in Group $3^{*}$

\begin{tabular}{|c|c|c|c|c|c|c|c|c|c|}
\hline & \multirow[b]{2}{*}{ Age } & \multirow[b]{2}{*}{$\operatorname{Sex}$} & \multirow[b]{2}{*}{ B.S.A. } & \multirow[b]{2}{*}{$\mathbf{P}_{\mathbf{B}}$} & \multicolumn{2}{|c|}{ Predicted values } & \multicolumn{2}{|c|}{ Measured values } & \multirow{2}{*}{$\begin{array}{l}\text { Per cent } \\
\text { predicted } \\
\text { V.C. }\end{array}$} \\
\hline & & & & & V.C. & M.B.C. & V.C. & M.B.C. & \\
\hline $\begin{array}{l}\text { 14. D. R. } \\
\text { 15. V. N. } \\
\text { 16. J. W. } \\
\text { 17. D. Do. } \\
\text { 18. M. C. } \\
\text { 19. R. F. }\end{array}$ & $\begin{array}{l}44 \\
26 \\
24 \\
26 \\
21 \\
54\end{array}$ & $\begin{array}{l}\mathbf{F} \\
\mathbf{F} \\
\mathbf{F} \\
\mathbf{F} \\
\mathbf{F} \\
\mathbf{F}\end{array}$ & $\begin{array}{l}1.73 \\
1.31 \\
1.55 \\
1.67 \\
1.41 \\
1.54\end{array}$ & $\begin{array}{l}756 \\
757 \\
766 \\
756 \\
757 \\
747\end{array}$ & $\begin{array}{l}2,930 \\
3, \overline{013} \\
3,140 \\
3,120 \\
2,340\end{array}$ & $\begin{array}{c}\frac{87}{109} \\
\frac{95}{73}\end{array}$ & $\begin{array}{l}3,380 \\
3 \overline{3} \\
3,450 \\
2,250 \\
2,390\end{array}$ & $\begin{array}{c}\frac{109}{81} \\
\frac{102}{79}\end{array}$ & $\begin{array}{r}115 \\
125 \\
115 \\
72 \\
102\end{array}$ \\
\hline
\end{tabular}

* See footnote to Table II for explanation of abbreviations.

TABLE IX

Ventilatory data and arterial blood tensions of patients in Group 3*

\begin{tabular}{|c|c|c|c|c|c|c|c|c|c|c|c|}
\hline & Pion & $\mathrm{P}^{\mathbf{A O}_{2}}$ & $\mathrm{PaO}_{2}$ & Pacon & $\mathrm{PecO}_{2}$ & $\dot{\mathbf{V}}_{\mathbf{E}}$ & f & $V_{D^{\text {app. }}}$ & $\dot{\mathrm{VO}}_{2}$ & $\mathbf{R}$ & $\mathrm{T}$ \\
\hline 14. D. R. & $\begin{array}{l}148 \\
100\end{array}$ & $\begin{array}{r}108 \\
64\end{array}$ & $\begin{array}{l}97 \\
53\end{array}$ & $\begin{array}{l}36 \\
33\end{array}$ & $\begin{array}{l}23 \\
22\end{array}$ & $\begin{array}{l}8.8 \\
7.8\end{array}$ & $\begin{array}{l}10 \\
11\end{array}$ & $\begin{array}{l}110 \\
110\end{array}$ & $\begin{array}{l}264 \\
217\end{array}$ & $\begin{array}{l}.88 \\
.90\end{array}$ & 二 \\
\hline 15. V. N. & $\begin{array}{r}149 \\
99\end{array}$ & $\begin{array}{r}119 \\
65\end{array}$ & $\begin{array}{l}95 \\
52\end{array}$ & $\begin{array}{l}24 \\
30\end{array}$ & $\begin{array}{l}18 \\
22\end{array}$ & $\begin{array}{l}6.2 \\
7.5\end{array}$ & $\begin{array}{l}18 \\
17\end{array}$ & $\begin{array}{l}35 \\
35\end{array}$ & $\begin{array}{l}156 \\
169\end{array}$ & $\begin{array}{l}.81 \\
.86\end{array}$ & $\begin{array}{l}15 \\
15\end{array}$ \\
\hline 16. J. W. & $\begin{array}{r}150 \\
82\end{array}$ & $\begin{array}{r}102 \\
50\end{array}$ & $\begin{array}{l}91 \\
41\end{array}$ & $\begin{array}{l}38 \\
32\end{array}$ & $\begin{array}{l}26 \\
22\end{array}$ & $\begin{array}{l}4.4 \\
7.5\end{array}$ & $\begin{array}{l}11 \\
10\end{array}$ & $\begin{array}{l}35 \\
35\end{array}$ & $\begin{array}{l}158 \\
192\end{array}$ & $\begin{array}{r}.81 \\
1.03\end{array}$ & $\begin{array}{l}14 \\
15\end{array}$ \\
\hline 17. D. Do. & $\begin{array}{r}148 \\
81\end{array}$ & $\begin{array}{r}102 \\
50\end{array}$ & $\begin{array}{l}88 \\
34\end{array}$ & $\begin{array}{l}32 \\
28\end{array}$ & $\begin{array}{l}25 \\
22\end{array}$ & $\begin{array}{l}7.4 \\
9.4\end{array}$ & $\begin{array}{l}17 \\
15\end{array}$ & $\begin{array}{l}35 \\
35\end{array}$ & $\begin{array}{l}301 \\
256\end{array}$ & $\begin{array}{l}.70 \\
.91\end{array}$ & $\begin{array}{l}13 \\
13\end{array}$ \\
\hline 18. M. C. & $\begin{array}{l}148 \\
101\end{array}$ & $\begin{array}{r}109 \\
67\end{array}$ & $\begin{array}{l}89 \\
46\end{array}$ & $\begin{array}{l}34 \\
32\end{array}$ & $\begin{array}{l}20 \\
19\end{array}$ & $\begin{array}{l}7.5 \\
8.9\end{array}$ & $\begin{array}{l}21 \\
21\end{array}$ & $\begin{array}{l}55 \\
55\end{array}$ & $\begin{array}{l}215 \\
207\end{array}$ & $\begin{array}{l}.82 \\
.94\end{array}$ & 12 \\
\hline 19. R. F. & $\begin{array}{r}147 \\
89\end{array}$ & $\begin{array}{r}111 \\
51\end{array}$ & $\begin{array}{l}98 \\
41\end{array}$ & $\begin{array}{l}32 \\
39\end{array}$ & $\begin{array}{l}23 \\
23\end{array}$ & $\begin{array}{l}7.2 \\
7.6\end{array}$ & $\begin{array}{l}10 \\
20\end{array}$ & $\begin{array}{l}55 \\
55\end{array}$ & $\begin{array}{l}218 \\
197\end{array}$ & $\begin{array}{r}.89 \\
1.02\end{array}$ & $\begin{array}{l}10 \\
10 \frac{1}{2}\end{array}$ \\
\hline
\end{tabular}

* See table of symbols for definitions of headings. 
DOUGLAS CARROLL, JEROME E. COHN, AND RICHARD L. RILEY

TABLE $X$

Distribution, diffusion, and hemodymamic findings on patients in Group 3*

\begin{tabular}{|c|c|c|c|c|c|c|c|c|c|c|}
\hline & $V_{D^{0}}$ & $\begin{array}{c}V_{D^{e}} / V_{T^{0}} \\
\times 100 \\
\end{array}$ & $\begin{array}{l}\dot{Q} v a / \dot{Q} t \\
\times 100\end{array}$ & $\mathrm{Do}_{2} / \mathrm{m}^{2} \dagger$ & $\frac{\text { Press }}{\text { PA(m) }}$ & $\frac{\text { Ires }}{\text { Cap.f }}$ & $\begin{array}{r}\text { Measured } \\
\mathrm{Sa}-\mathrm{S} \overline{\mathbf{v}} \\
\end{array}$ & $\begin{array}{l}\text { Assumed } \\
\mathbf{S c}^{\circ}-\mathrm{Sv}\end{array}$ & C.I.f & Dyspnea \\
\hline 14. D. R. & $\begin{array}{l}202 \\
125\end{array}$ & $\begin{array}{l}24 \\
22\end{array}$ & 4 & 5 & & & & 30 & & ++ \\
\hline 15. V. N. & $\begin{array}{l}65 \\
90\end{array}$ & $\begin{array}{l}20 \\
22\end{array}$ & 4 & 5 & 75 & & 47 & 50 & 1.71 & + \\
\hline 16. J. W. & $\begin{array}{l}110 \\
183\end{array}$ & $\begin{array}{l}26 \\
26\end{array}$ & 5 & 8 & & & & 30 & & + \\
\hline 17. D. Do. & $\begin{array}{r}67 \\
105\end{array}$ & $\begin{array}{l}17 \\
18\end{array}$ & 6 & 8 & 31 & 25 & 23 & 25 & & + \\
\hline 18. M. C. & $\begin{array}{r}88 \\
110\end{array}$ & $\begin{array}{l}29 \\
33\end{array}$ & 6 & 5 & 38 & 21 & 34 & 35 & 3.40 & + \\
\hline 19. R. F. & $\begin{array}{r}142 \\
97\end{array}$ & $\begin{array}{l}21 \\
30\end{array}$ & 4 & 8 & 28 & 27 & 28 & 30 & 2.31 & + \\
\hline
\end{tabular}

* See table of symbols for definitions of headings.

$\$$ See footnotes to Table IV.

capacity was measured in four and was normal in three. Pulmonary vascular pressures were elevated in the four patients who were catheterized.

Exertional dyspnea was marked in Case 14 and moderate in the remainder. Cases 15, 16, and 19 had apical systolic murmurs in addition to apical diastolic murmurs.

\section{Low diffusing capacity with abnormal distribution -Group 4 (Tables XI, XII, and XIII)}

Ten patients had low diffusing capacities and abnormal distribution of blood and gas. Two studies are recorded for Case 24. The second study was done when the patient had reached optimal cardiac compensation and is used for comparison with the studies on other patients in this series. Four patients had high dead space to tidal volume ratios with normal venous admixture to total flow ratios. One case had normal dead space to tidal volume ratio with high venous admixture ratio. The remaining six patients had elevation of both dead space and venous admixture ratios.

The vital capacity was reduced in all cases in Group 4, but in five, the maximal breathing capacity was normal.

In eight patients pulmonary arterial pressure

TABLE XI

Physical characteristics, vital capacity, and maximal breathing capacity of patients in Group $4^{*}$

\begin{tabular}{|c|c|c|c|c|c|c|c|c|c|}
\hline & \multirow[b]{2}{*}{ Age } & \multirow[b]{2}{*}{ Sex } & \multirow[b]{2}{*}{ B.S.A. } & \multirow[b]{2}{*}{$\mathbf{P}_{\mathbf{B}}$} & \multicolumn{2}{|c|}{ Predicted values } & \multicolumn{2}{|c|}{ Measured values } & \multirow{2}{*}{$\begin{array}{l}\text { Percent } \\
\text { predicted } \\
\text { V.C. }\end{array}$} \\
\hline & & & & & V.C. & M.B.C. & V.C. & $\overline{\text { M.B.C. }}$ & \\
\hline $\begin{array}{l}\text { 20. G. B. } \\
\text { 21. F. G. } \\
\text { 22. E. G. } \\
\text { 23. J. A. } \\
\text { 24. R. D. } \\
\text { R. D. } \\
\text { 25. L. E. } \\
\text { 26. G. M. } \\
\text { 27. M. C. } \\
\text { 28. R. R. } \\
\text { 29. B. L. }\end{array}$ & $\begin{array}{l}39 \\
25 \\
28 \\
24 \\
39 \\
39 \\
32 \\
44 \\
40 \\
43 \\
39\end{array}$ & $\begin{array}{l}\mathbf{F} \\
\mathbf{F} \\
\mathbf{M} \\
\mathbf{F} \\
\mathbf{F} \\
\mathbf{F} \\
\mathbf{F} \\
\mathbf{F} \\
\mathbf{M} \\
\mathbf{F}\end{array}$ & $\begin{array}{l}1.53 \\
1.53 \\
1.43 \\
1.99 \\
1.45 \\
1.45 \\
1.39 \\
1.41 \\
1.44 \\
1.58 \\
1.59\end{array}$ & $\begin{array}{l}763 \\
761 \\
768 \\
756 \\
764 \\
750 \\
765 \\
752 \\
749 \\
762 \\
754\end{array}$ & $\begin{array}{l}2,920 \\
3,125 \\
3,500 \\
4,560 \\
2,890 \\
2,890 \\
2,700 \\
2,810 \\
2,705 \\
3,480 \\
-\end{array}$ & $\begin{array}{r}85 \\
95 \\
99 \\
147 \\
77 \\
77 \\
82 \\
86 \\
83 \\
101 \\
\end{array}$ & $\begin{array}{l}2,760 \\
2,830 \\
2,850 \\
3,480 \\
1,968 \\
2,080 \\
2,420 \\
2,360 \\
2,162 \\
3,280 \\
-\end{array}$ & $\begin{array}{r}84 \\
93 \\
57 \\
83 \\
88 \\
100 \\
68 \\
43 \\
98 \\
95 \\
-\end{array}$ & $\begin{array}{l}95 \\
91 \\
82 \\
76 \\
72 \\
84 \\
80 \\
94 \\
\end{array}$ \\
\hline
\end{tabular}

* See footnote to Table II for explanation of abbreviations.

† Case 24 was restudied three days prior to operation, at which time she was in optimal clinical condition. 
PULMONARY FUNCTION IN MITRAL VALVULAR DISEASE

TABLE XII

Ventilatory data and arterial blood tensions of patients in Group $4^{*}$

\begin{tabular}{|c|c|c|c|c|c|c|c|c|c|c|c|}
\hline & $\mathrm{Proz}_{2}$ & $\mathrm{P}_{\mathrm{AO}_{2}}$ & $\mathrm{Pao}_{2}$ & $\mathrm{Pacoz}_{2}$ & Pecon & $\dot{\mathbf{V}}_{\mathbf{E}}$ & $\mathbf{f}$ & $V_{D^{a p p .}}$ & $\dot{\mathrm{VO}}_{2}$ & $\mathbf{R}$ & $\mathbf{T}$ \\
\hline 20. G. B. & $\begin{array}{r}150 \\
96\end{array}$ & $\begin{array}{l}98 \\
55\end{array}$ & $\begin{array}{l}94 \\
46\end{array}$ & $\begin{array}{l}42 \\
38\end{array}$ & $\begin{array}{l}22 \\
21\end{array}$ & $\begin{array}{l}6.2 \\
6.4\end{array}$ & $\begin{array}{l}18 \\
18\end{array}$ & $\begin{array}{l}35 \\
35\end{array}$ & $\begin{array}{l}205 \\
172\end{array}$ & $\begin{array}{l}.78 \\
.92\end{array}$ & $\begin{array}{l}13 \\
15\end{array}$ \\
\hline 21. F. G. & $\begin{array}{l}149 \\
105\end{array}$ & $\begin{array}{r}111 \\
65\end{array}$ & $\begin{array}{l}93 \\
51\end{array}$ & $\begin{array}{l}36 \\
35\end{array}$ & $\begin{array}{l}19 \\
19\end{array}$ & $\begin{array}{l}8.9 \\
9.6\end{array}$ & $\begin{array}{l}22 \\
21\end{array}$ & $\begin{array}{l}55 \\
55\end{array}$ & $\begin{array}{l}208 \\
205\end{array}$ & $\begin{array}{r}.94 \\
. \quad .98\end{array}$ & $\begin{array}{l}15 \\
12\end{array}$ \\
\hline 22. E. G. & $\begin{array}{r}152 \\
88\end{array}$ & $\begin{array}{r}105 \\
55\end{array}$ & $\begin{array}{l}88 \\
41\end{array}$ & $\begin{array}{l}41 \\
33\end{array}$ & $\begin{array}{l}25 \\
22\end{array}$ & $\begin{array}{l}5.8 \\
6.9\end{array}$ & $\begin{array}{l}13 \\
15\end{array}$ & $\begin{array}{l}55 \\
55\end{array}$ & $\begin{array}{l}236 \\
209\end{array}$ & $\begin{array}{r}.87 \\
1.00\end{array}$ & $\begin{array}{l}15 \\
13 \frac{1}{2}\end{array}$ \\
\hline 23. J.A. & $\begin{array}{r}148 \\
98\end{array}$ & $\begin{array}{r}108 \\
67\end{array}$ & $\begin{array}{l}78 \\
47\end{array}$ & $\begin{array}{l}36 \\
34\end{array}$ & $\begin{array}{l}20 \\
19\end{array}$ & $\begin{array}{l}12.5 \\
14.7\end{array}$ & $\begin{array}{l}19 \\
18\end{array}$ & $\begin{array}{l}35 \\
35\end{array}$ & $\begin{array}{l}322 \\
296\end{array}$ & $\begin{array}{r}.91 \\
1.09\end{array}$ & $=$ \\
\hline 24. R. D.† & $\begin{array}{l}175 \\
129\end{array}$ & $\begin{array}{l}143 \\
104\end{array}$ & $\begin{array}{l}52 \\
41\end{array}$ & $\begin{array}{l}27 \\
23\end{array}$ & $\begin{array}{l}15 \\
13\end{array}$ & $\begin{array}{l}11.9 \\
15.0\end{array}$ & $\begin{array}{l}22 \\
27\end{array}$ & $\begin{array}{l}65 \\
65\end{array}$ & $\begin{array}{l}245 \\
219\end{array}$ & $\begin{array}{r}.82 \\
1.00\end{array}$ & $=$ \\
\hline R. D. & $\begin{array}{l}147 \\
112\end{array}$ & $\begin{array}{r}105 \\
73\end{array}$ & $\begin{array}{l}88 \\
56\end{array}$ & $\begin{array}{l}39 \\
35\end{array}$ & $\begin{array}{l}20 \\
18\end{array}$ & $\begin{array}{l}8.3 \\
7.8\end{array}$ & $\begin{array}{l}16 \\
15\end{array}$ & $\begin{array}{l}110 \\
110\end{array}$ & $\begin{array}{l}215 \\
178\end{array}$ & $\begin{array}{l}.91 \\
.87\end{array}$ & $=$ \\
\hline 25. L. E. & $\begin{array}{r}152 \\
88\end{array}$ & $\begin{array}{r}106 \\
57\end{array}$ & $\begin{array}{l}81 \\
39\end{array}$ & $\begin{array}{l}38 \\
35\end{array}$ & $\begin{array}{l}22 \\
20\end{array}$ & $\begin{array}{l}7.7 \\
8.6\end{array}$ & $\begin{array}{l}19 \\
13\end{array}$ & $\begin{array}{l}55 \\
55\end{array}$ & $\begin{array}{l}235 \\
178\end{array}$ & $\begin{array}{r}.82 \\
1.13\end{array}$ & $\begin{array}{r}10 \\
9\end{array}$ \\
\hline 26. G. M. & $\begin{array}{r}148 \\
86\end{array}$ & $\begin{array}{r}112 \\
58\end{array}$ & $\begin{array}{l}80 \\
38\end{array}$ & $\begin{array}{l}33 \\
30\end{array}$ & $\begin{array}{l}18 \\
16\end{array}$ & $\begin{array}{r}9.2 \\
10.9\end{array}$ & $\begin{array}{l}21 \\
18\end{array}$ & $\begin{array}{l}55 \\
55\end{array}$ & $\begin{array}{l}213 \\
183\end{array}$ & $\begin{array}{r}.92 \\
1.08\end{array}$ & $\begin{array}{l}10 \\
10\end{array}$ \\
\hline 27. M. C. & $\begin{array}{r}149 \\
89\end{array}$ & $\begin{array}{r}109 \\
60\end{array}$ & $\begin{array}{l}84 \\
47\end{array}$ & $\begin{array}{l}33 \\
30\end{array}$ & $\begin{array}{l}19 \\
16\end{array}$ & $\begin{array}{r}8.4 \\
11.6\end{array}$ & $\begin{array}{l}21 \\
23\end{array}$ & $\begin{array}{l}55 \\
55\end{array}$ & $\begin{array}{l}223 \\
204\end{array}$ & $\begin{array}{r}.82 \\
1.05\end{array}$ & $\begin{array}{c}10 \\
9 \frac{1}{2}\end{array}$ \\
\hline 28. R. R. & $\begin{array}{r}150 \\
95\end{array}$ & $\begin{array}{l}97 \\
54\end{array}$ & $\begin{array}{l}80 \\
36\end{array}$ & $\begin{array}{l}45 \\
39\end{array}$ & $\begin{array}{l}22 \\
18\end{array}$ & $\begin{array}{r}8.4 \\
11.3\end{array}$ & $\begin{array}{l}19 \\
22\end{array}$ & $\begin{array}{l}55 \\
55\end{array}$ & $\begin{array}{l}256 \\
237\end{array}$ & $\begin{array}{l}.82 \\
.95\end{array}$ & $\begin{array}{l}10 \\
14 \frac{1}{2}\end{array}$ \\
\hline 29. B. L. & $\begin{array}{r}147 \\
98\end{array}$ & $\begin{array}{l}94 \\
57\end{array}$ & $\begin{array}{l}91 \\
46\end{array}$ & $\begin{array}{l}41 \\
38\end{array}$ & $\begin{array}{l}18 \\
16\end{array}$ & $\begin{array}{l}5.6 \\
7.5\end{array}$ & $\begin{array}{l}21 \\
27\end{array}$ & $\begin{array}{l}65 \\
65\end{array}$ & $\begin{array}{l}160 \\
153\end{array}$ & $\begin{array}{l}.73 \\
.92\end{array}$ & $=$ \\
\hline
\end{tabular}

* See table of symbols for definitions of headings.

† Study performed during cardiac catheterization one and one-half months prior to operation.

$\ddagger$ Respiratory study done three days prior to operation at which time the patient was in optimal clinical condition.

was obtained at rest and was uniformly elevated. Pulmonary "capillary" pressure, obtained in six, was elevated in all except Case 22. In this patient, catheterization was repeated, and the same low "capillary" pressure was obtained. All patients in Group 4 had severe dyspnea on exertion, being unable to walk up a flight of stairs without stopping. All had severer dyspnea than any patient in any other group.

\section{DISCUSSION}

\section{Further remarks on technical matters}

Since the findings in these studies have led to the grouping of patients in four categories and since the data will be interpreted in terms of this grouping, it is important to be sure that technical errors have not led to a false classification. The likelihood of errors in classification resulting from erroneous estimates of mixed venous blood satura- tion can be judged from Table I. The use of the values for venous admixture ratio and diffusing capacity appearing in columns 1 or $3\left(\mathrm{Sc}^{\ominus}-\mathrm{S} \bar{v}=\right.$ 20 or $\mathrm{Sc}^{\ominus}-\mathrm{S} \overline{\mathrm{v}}=40$ ) would cause Case 1 to move from Group 1 to Group 2, Case 10 to move from Group 2 to Group 3 and Case 22 to move from Group 4 to Group 3. Thus, Groups 1, 2, and 4 would remain intact with the exception of one case in each group. Group 3 is less solidly established since the classification of four of the six patients (Cases 15, 16, 17, and 18) would be changed as a result of possible errors in the assumed values for mixed venous blood saturation. This is a manifestataion of the fact that the patients in Group 3 tend to be close to the borderline between normal and abnormal with respect to both diffusion and distribution.

The classification might also be altered as a result of the patient's not having reached a steady state during low oxygen breathing. This type of 
error, by producing erroneously low values for diffusing capacity, might have caused patients, who belonged in Groups 1 and 2, to be placed in Groups 3 and 4. Again, suspicion falls upon the borderline cases in Group 3, some of whom might have shifted to Group 1 if they had reached a steady state. It is less likely that the cases in Group 4 were improperly classified because most of them had such low diffusing capacities that even a considerable increase would not have brought them into the normal range.

\section{Clinical correlations}

Of the clinical signs and symptoms, the degree of exertional dyspnea was best correlated with the physiological grouping. In Group 1, dyspnea was mild or absent; in Groups 2 and 3, it was mild or moderate; in Group 4 it was uniformly severe.
Dyspnea has long been considered a manifestation of pulmonary congestion, which, as will appear below, contributes to abnormalities of distribution. Dyspnea is also associated with impaired diffusion (24). It is not surprising, therefore, that the patients in Group 4, who had impairment of both distribution and diffusion, suffered from the most severe dyspnea.

There was no correlation between the duration of signs and symptoms and the severity of the physiological abnormalities in these patients.

\section{Pulmonary vascular pressures}

In three patients the pulmonary "capillary" pressure may have been in error. In Cases 3 and 19 , the mean pulmonary arterial and "capillary" pressures were so close that there is a question as to whether the catheter was adequately wedged

TABLE XIII

Distribution, diffusion, and hemodynamic findings on patients in Group $4^{*}$

\begin{tabular}{|c|c|c|c|c|c|c|c|c|c|c|}
\hline & $V_{D^{0}}$ & $\begin{array}{c}V_{\mathbf{D}^{\mathrm{e}} / \mathrm{V}_{\mathbf{T}^{\mathrm{e}}}} \times 100\end{array}$ & $\underset{\times 100}{\dot{Q} v a / \dot{Q} t}$ & $\mathrm{Do}_{2} / \mathrm{m}^{2} \dagger$ & $\frac{\text { Press }}{\text { PA(m) }}$ & $\frac{\text { ures }}{\text { Cap. } \neq}$ & $\begin{array}{l}\text { Measured } \\
\mathrm{Sa}-\mathrm{S} \overline{\mathrm{v}}\end{array}$ & $\begin{array}{l}\text { Assumed } \\
\mathrm{S}^{\circ}-\mathrm{S} \overline{\mathbf{v}}\end{array}$ & C.I. & Dyspnea \\
\hline 20. G. B. & $\begin{array}{l}131 \\
124\end{array}$ & $\begin{array}{l}43 \\
38\end{array}$ & 2 & 6 & 45 & 19 & 30 & 30 & 1.89 & +++ \\
\hline 21. F. G. & $\begin{array}{l}137 \\
161\end{array}$ & $\begin{array}{l}38 \\
39\end{array}$ & 4 & 5 & 65 & 6 & 42 & 40 & 1.97 & +++ \\
\hline 22. E. G. & $\begin{array}{l}119 \\
110\end{array}$ & $\begin{array}{l}30 \\
26\end{array}$ & 7 & 7 & 43 & 22 & 30 & 30 & 2.39 & +++ \\
\hline 23. J. A. & $\begin{array}{l}271 \\
324\end{array}$ & $\begin{array}{l}43 \\
42\end{array}$ & 13 & 6 & $88 \|$ & $32 \|$ & $30 \|$ & 30 & $2.92 \|$ & +++ \\
\hline 24. R. D. & $\begin{array}{l}184 \\
211\end{array}$ & $\begin{array}{l}39 \\
43\end{array}$ & 26 & 2 & 94 & - & 35 & 50 & 2.60 & +++ \\
\hline R. D. & $\begin{array}{l}148 \\
144\end{array}$ & $\begin{array}{l}35 \\
35\end{array}$ & 6 & 4 & & & - & 30 & & +++ \\
\hline 25. L. E. & $\begin{array}{l}124 \\
219\end{array}$ & $\begin{array}{l}35 \\
37\end{array}$ & 7 & 5 & 57 & - & 54 & 50 & 2.00 & +++ \\
\hline 26. G. M. & $\begin{array}{l}141 \\
238\end{array}$ & $\begin{array}{l}37 \\
43\end{array}$ & 11 & 5 & 49 & 18 & 36 & 35 & 1.52 & +++ \\
\hline 27. M. C. & $\begin{array}{l}122 \\
181\end{array}$ & $\begin{array}{l}35 \\
40\end{array}$ & 7 & 6 & 47 & 27 & 43 & 40 & 1.75 & +++ \\
\hline 28. R. R. & $\begin{array}{l}169 \\
224\end{array}$ & $\begin{array}{l}45 \\
48\end{array}$ & 8 & 7 & & & & 30 & & +++ \\
\hline 29. B. L. & $\begin{array}{r}87 \\
124\end{array}$ & $\begin{array}{l}42 \\
47\end{array}$ & 1 & 5 & & & & 30 & & +++ \\
\hline
\end{tabular}

* See table of symbols for definitions of headings.

$t$
$\$$

See footnotes to Table IV.

Values obtained at catheterization 10 months after respiratory studies. 
when the pulmonary "capillary" pressure was recorded. In Case 21, the pulmonary "capillary" pressure was found to be $6 \mathrm{~mm}$. $\mathrm{Hg}$ on two different occasions. This patient had severe mitral stenosis at operation and was dramatically improved by commissurotomy. It seems unlikely that such a low pulmonary "capillary" pressure could exist in a patient with severe mitral stenosis.

Some evidence regarding the early sequence of events in patients with mitral stenosis can be gleaned from the studies in Group 1. Among these patients with normal respiratory function, there were three whose pulmonary arterial pressures were measured, and in two of these, the pressure was significantly elevated. Thus it appears that elevation of pulmonary vascular pressures may precede abnormalities of pulmonary function as measured by the technics used in this study.

Further correlations between hemodynamic and respiratory findings are uncertain because the measurements were not simultaneous. For purposes of this report, the hemodynamic data simply serve to indicate, in terms which have become relatively familiar, the severity of the disease process under consideration.

\section{Vital capacity and maximal breathing capacity}

The vital capacity and maximal breathing capacity were usually normal in Groups 1 and 3 and were usually reduced in Groups 2 and 4 . In patients with cardiac disease, a low vital capacity and reduced maximal breathing capacity have long been thought to indicate pulmonary congestion. These changes may result from decreased lung distensibility and retractability and from obstruction of the smaller airways caused by tissue edema and free fluid within the airways.

\section{Distribution characteristics}

In general, variations in the ventilation-perfusion ratio in different parts of the lung tend to elevate both the venous admixture ratio and the dead space ratio (13). Obstruction of airways may permit perfusion of poorly ventilated areas and lead to a high venous admixture ratio, while obstruction of blood channels may permit ventilation of poorly perfused areas and lead to a high dead space ratio. Because of their common relationship to vascular congestion and edema, it is not surprising that reduction in vital capacity and maximal breathing capacity proved to be characteristic of the same groups in which the distribution of gas and blood to the alveoli was abnormal (Groups 2 and 4).

This relationship is supported by the correlation between vital capacity and dead space ratio shown in Figure 1. The correlation is as good as can be expected between two functions which are affected independently by factors other than vascular congestion and edema. It is at least consistent with

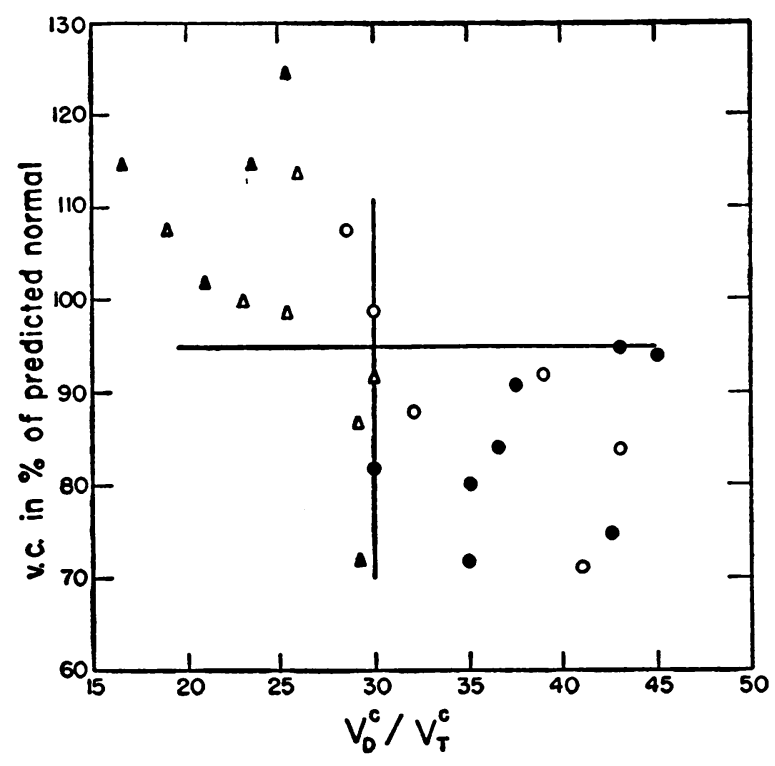

Fig. 1. Correlation between Vital Capacity and Dead Space Ratio

Open triangle $=$ Group 1 .

Closed triangle $=$ Group 3.

Open circle = Group 2.

Closed circle = Group 4 .

the belief that both the vital capacity and the dead space ratio are affected to a significant degree by vascular congestion and edema.

Additional evidence for this belief is provided by the comparison of findings before and after mitral commissurotomy. In Table XIV such findings on three patients are present. The vital capacity and maximal breathing capacity tended to increase after operation. The dead space ratio decreased by a significant amount, and the venous admixture ratio did not change appreciably. Since mitral commissurotomy is usually followed by a decrease in pulmonary capillary pressure (9) and 
TABLE XIV

The findings in three patients studied at rest pre-operatively and post-operatively

\begin{tabular}{|c|c|c|c|c|c|c|}
\hline & \multicolumn{2}{|c|}{ Case 8} & \multicolumn{2}{|c|}{ Case 24} & \multicolumn{2}{|c|}{ Case 30} \\
\hline & Pre-op. & $\begin{array}{l}12 \text { mos. } \\
\text { Post-op. }\end{array}$ & $\begin{array}{l}3 \text { days } \\
\text { Pre-op. }\end{array}$ & $\begin{array}{l}11 \text { mos. } \\
\text { Post-op. }\end{array}$ & Pre-op. & $\begin{array}{l}11 \text { mos. } \\
\text { Post-op. }\end{array}$ \\
\hline $\begin{array}{l}\text { V.C. }{ }^{*} \\
\text { M.B.C.* } \\
\text { V }^{\circ} / \text { VT }^{\circ} \times 100 t\end{array}$ & $\begin{array}{r}2,760 \\
70 \\
39\end{array}$ & $\begin{array}{r}2,800 \\
92 \\
29\end{array}$ & $\begin{array}{r}2,080 \\
100 \\
35\end{array}$ & $\begin{array}{r}2,125 \\
87 \\
27\end{array}$ & $\begin{array}{r}2,100 \\
73 \\
42\end{array}$ & $\begin{array}{r}2,390 \\
87 \\
35\end{array}$ \\
\hline 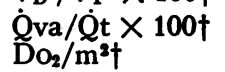 & $\stackrel{2}{\mathrm{~N}}$ & 1 & $\begin{array}{l}6 \\
4\end{array}$ & $\begin{array}{l}7 \\
6\end{array}$ & $\stackrel{4}{-7}$ & $\stackrel{2}{\mathrm{~N}}$ \\
\hline
\end{tabular}

\footnotetext{
* See footnote to Table II.

$\dagger$ See table of symbols for definition.

$\ddagger$ The pre-operative low level study on this patient was unsatisfactory and a pre-operative.diffusing capacity therefore was not obtained. For this reason, the patient could not be classified and is not included in the other tables.
}

hence, presumably, in the tendency for fluid to escape from the capillaries, the decrease in dead space ratio after operation may well have resulted from decreased pulmonary vascular congestion and edema.

The increase in venous admixture ratio in most of the patients in Groups 2 and 4 is consistent with the findings of Blount, McCord, and Anderson (28).

\section{Diffusion characteristics}

A low diffusing capacity is attributed to abnormalities in the character of the diffusing surface or to reduction in its total effective area, i.e., the area of the capillary walls across which gas exchange takes place. These changes may be either structural or functional in nature.

Although histological evidence for structural changes in the diffusing surface in mitral stenosis has been presented (1), the changes are usually not striking and it is difficult to evaluate their importance. The possibility that physico-chemical changes may alter the ease with which oxygen diffuses per unit area, without altering the appearance of the microscopic section, must be acknowledged but cannot be evaluated. Pulmonary edema produces a structural change in the character of the pulmonary membrane but the degree of edema presumed to be present in Group 2 did not cause a significant decrease in the diffusing capacity at rest. Several mechanisms for reduction, in the area of the diffusing surface, may be postulated. Parker and Weiss provided suggestive, but not conclusive, evidence for loss of capillaries, based on direct capillary counts (1). Degenerative changes, leading to elimination of capillaries, would seem a not unlikely result of prolonged capillary hypertension and might also arise as a direct effect of the rheumatic process. Interruption of pulmonary capillary blood flow by small emboli must also be considered, because evidence of embolization is frequently found in patients dying of mitral stenosis (25).

The most convincing evidence for functional changes in the pulmonary membrane is provided by the increase in diffusing capacity which occurs with exercise. The fact that such an increase occurs has been demonstrated repeatedly both in normal subjects and in patients with mitral disease. The explanation would seem to require either that the permeability to oxygen of the diffusing surface increase with exercise, or that its area broaden. While no proof is available, it seems likely that the area of the perfused portion of the pulmonary capillary bed might increase, but unlikely that the diffusion characteristics of the capillary walls and alveolar membrane should change. From these reasonable assumptions it is postulated: 1) That the area of the active diffusing surface increases during exercise; 2) conversely, that part of the surface, across which diffusion takes place during exercise, is inactive in the resting state; and 3) that this reduction results, in large measure, from the cutting off of blood flow through portions of the capillary bed.

A way in which such dynamic changes in the diffusing surface might be brought about is suggested by the work of Burton, Nichols, Girling, Jerrard, and Claxton $(26,27)$. These workers inferred, from careful studies of the circulation of the rabbit's ear and hind limb, that small vessels close completely at pressures below a certain level, 
called the critical closing pressure. They also found evidence that the critical closing pressure rises as the tone in the vessel walls increases.

If these ideas are applied in the case of mitral stenosis, it would seem possible that some of the small pulmonary vessels close in the resting state because the pressure tending to hold them open is less than the critical closing pressure. As a consequence, blood flow through some of the capillaries may be eliminated with resultant reduction in the area of the active diffusing surface and reduction in the diffusing capacity as determined. Such a mechanism would account for the dynamic changes in the capillary bed which were postulated to explain the difference between the diffusing capacity at rest and during exercise. ${ }^{5}$

The objection might be raised that the pulmonary vascular pressures are high in mitral stenosis and that, therefore, all vessels must necessarily be open even in the resting state. To this it could be answered that the pulmonary vascular resistance is also high in mitral stenosis, suggesting that the tone of the small vessels, and hence their critical closing pressure, is high. Probably the balance between the pressures tending to hold the vessels open and the vasomotor tone, tending to close them, determines which vessels remain patent and which do not.

It may be postulated that gas exchange takes place across virtually all capillary walls during strenuous exercise, and that the diffusing capacity, determined under these conditions, is related to the structural characteristics of the entire diffusing surface of the lung (17). If this is so, the highest value obtainable during exercise, called the maximal diffusing capacity, may be interpreted in static morphologic terms. Values obtained at rest, on the other hand, are almost certainly affected by dynamic, as well as static, factors. It is therefore felt, that quantitative interpretations regarding the over-all structure of the diffusing surface are not justified by knowledge of the resting diffusing capacity alone.

The low values for diffusing capacity found in the patients in Groups 3 and 4 indicate simply that the summation of morphologic and physiologic factors, affecting the diffusing surface in the resting state in patients with mitral stenosis, may lead to

- These mechanisms would apply to normal as well as pathological states. a lower-than-normal value. The differences between Groups 2 and 3 demonstrate that significant abnormalities of diffusion and distribution may occur independently.

\section{Pathogenesis of the pulmonary changes in patients with mitral stenosis}

The development of pulmonary changes in patients with mitral stenosis is presumably related to the well-recognized hemodynamic changes. As the mitral valve becomes deformed, the flow of blood through the narrowed valve is maintained by an increase in the diastolic pressure gradient between the left auricle and the left ventricle. This increase is brought about by elevation of the left auricular pressure, which is necessarily accompanied by elevation in pressure throughout all vessels up-stream from the auricle. The energy for these pressure changes is provided primarily by the right ventricle. The pressure is, thus, progressively higher in the pulmonary capillary bed and in the pulmonary artery. Cases 1, 3, and 5 demonstrate that elevation of pulmonary vascular pressures may precede other evidences of abnormal pulmonary function in the categories tested, although dyspnea, on exertion, may be present at this phase of the disease.

Abnormalities of alveolar function appear after the onset of vascular hypertension and are probably related to its duration and intensity. The alveolar dysfunction may take the form of distribution abnormality, which is manifested by elevation of the dead space ratio or the venous admixture ratio. Such abnormality is ordinarily associated with reduction in vital capacity and maximal breathing capacity and probably arises primarily as a result of vascular congestion and associated changes. In other cases, the first abnormality of alveolar function may be a low diffusing capacity, resulting either from structural changes in the diffusing surface or, possibly, from vasomotor changes eliminating blood flow in some of the capillaries. When the disease process becomes far advanced, combined abnormalities of distribution and diffusion are invariably found.

\section{SUM MARY}

Twenty-nine patients with mitral valvular disease were studied by methods designed to ex- 
plore pulmonary ventilation, circulation, distribution and diffusion. Dyspnea was the clinical feature best correlated with physiological abnormalities, being absent or slight in patients who displayed normal respiratory function and most severe in those who had evidence of impaired diffusion of oxygen and abnormal distribution of blood and gas to the alveoli. Impairment of distribution appeared to be related to the presence of at least minimal pulmonary edema. Impairment of diffusion, on the other hand, was related to capillary changes of a structural or functional nature, acting singly or in combination. The fact that abnormalities of distribution and diffusion often appeared independently suggested that the sequence of events in the development of altered pulmonary function in patients with mitral stenosis might vary from patient to patient. When the disease was far advanced, there were abnormalities in all aspects of pulmonary function which were studied.

\section{SYMBOLS}

\section{(In alphabetical order)}

$\mathrm{Do}_{2} / \mathrm{m}^{2}=$ diffusing capacity of the lungs per square meter body surface area.

f $\quad=$ respiratory rate in breaths per minute.

$\mathrm{N} \quad=$ normal.

$\mathrm{P}_{\mathrm{AO}_{2}}=$ "effective" alveolar $\mathrm{Po}_{2}$, in $\mathrm{mm} . \mathrm{Hg}$, as"specifically defined (13).

$\mathrm{Pao}_{2}=\operatorname{arterial} \mathrm{PO}_{3}$, in $\mathrm{mm}$. $\mathrm{Hg}$.

$\mathrm{Paco}_{2}=\operatorname{arterial} \mathrm{PCO}_{2}$, in $\mathrm{mm}$. $\mathrm{Hg}$.

$\overline{\mathrm{P}}_{\mathrm{oOg}}=$ mean partial pressure of oxygen in the pulmonary capillaries.

$\mathbf{P}_{\mathbf{B}} \quad=$ barometric pressure, in $\mathrm{mm}$. $\mathrm{Hg}$.

$\mathrm{PEco}_{2}=$ expired gas $\mathrm{PCO}_{2}$, in $\mathrm{mm}$. $\mathrm{Hg}$ B.T.P.S. (body temperature and pressure and saturated with water vapor).

$\mathrm{Plo}_{2}=$ inspired gas $\mathrm{PO}_{2}$, in $\mathrm{mm}$. $\mathrm{Hg}$ B.T.P.S.

$\dot{Q} \mathrm{va} / \dot{Q} \mathrm{t} \times 100=$ ratio of venous admixture to total blood flow, expressed as per cent.

$\mathrm{R}=$ the $\mathrm{CO}_{2}-\mathrm{O}_{2}$ exchange ratio or respiratory quotient.

$\mathrm{Sa} \quad=$ oxygen saturation of arterial blood.

Sc $\quad=$ oxygen saturation of "effective" capillary blood, i.e., blood leaving alveolar capillaries, as specifically defined (13).

Si $\quad=$ oxygen saturation of mixed venous blood.

$\mathrm{T}=$ time in minutes during which the patient approached a steady state, while breathing either room air or a low oxygen mixture, before samples of arterial blood and expired gas were collected for analysis.
$\mathbf{V}_{\mathbf{D}^{\text {\&pp. }}} \quad$ = apparatus dead space.

$\dot{\mathrm{V}}_{\mathrm{D}^{\circ}} \quad=$ physiological dead space, corrected for apparatus dead space in ml. B.T.P.S.

$V_{D^{\circ}} / V_{T^{\circ}} \times 100=$ ratio of dead space to tidal volume, both corrected for apparatus dead space, expressed as per cent.

$\dot{\mathrm{V}}_{\mathbf{E}} \quad=$ minute volume of expired gas, i.e., ventilation in L. per minute B.T.P.S.

$\dot{\mathrm{VO}}_{2}=\mathrm{O}_{2}$ consumption in ml. per minute S.T.P.D. (standard temperature and pressure, dry).

\section{ACKNOWLEDGMENT}

The authors wish to acknowledge the invaluable assistance of Dr. E. Cowles Andrus, who referred most of the patients to the laboratory and also gave encouragement, criticism and advice.

\section{REFERENCES}

1. Parker, F. Jr., and Weiss, S., The nature and significance of the structural changes in the lungs in mitral stenosis. Am. J. Path., 1936, 12, 573.

2. Larabee, W. F., Parker, R. F., and Edwards, J. F., Pathology of intrapulmonary arteries and arterioles in mitral stenosis. Proc. Staff Meeting, Mayo Clinic, 1949, 24, 316.

3. Welch, K. J., Johnson, J., and Zinsser, H., The significance of pulmonary vascular lesions in the selection of patients for mitral valve surgery. Ann. Surg., 1950, 132, 1027.

4. Ellis, L. G., Bloomfield, R. A., Graham, G. K., Greenberg, D. J., Hultgren, H. N., Krauts, H., Maresh, G., Mebane, J. G., Pfeiffer, P. H., Selverstone, L. A., and Taylor, J. A., Studies in mitral stenosis. I : A correlation of physiologic and clinical findings. Arch. Int. Med., 1951, 88, 515.

5. Graham, G. K., Taylor, J. A., Ellis, L. B., Greenberg, D. J., and Robbins, S. L., Studies in mitral stenosis. II : A correlation of postmortem findings with the clinical course of the disease in one hundred cases. Ibid., 532.

6. Rich, A. R., Personal communication.

7. Meakins, J. C., and Davies, H. W., Respiratory Function in Disease. Edinburgh, Oliver and Boyd, 1925.

8. Altschule, M. D., Physiology in Diseases of the Heart and Lungs, Harvard University, Cambridge, monographs in medicine and public health, no. 10. Harvard University Press, 1949.

9. Draper, A., Heimbecker, R., Daley, R., Carroll, D., Mudd, G., Wells, R. Falholt, W., Andrus, E. C., and Bing, R. J., Physiological studies in mitral valvular disease. Circulation, 1951, 3, 531.

10. Baldwin, E. DeF., Cournand, A., and Richards, D. W., Jr., Pulmonary insufficiency. I: Physiological classification, clinical methods of analysis, standard values in normal subjects. Medicine, 1948, 27, 243. 
11. Dexter, L., Dow, J. W., Haynes, F. W., Whittenberger, J. L., Ferris, B. G., Goodale, W. T., and Hellems, H. K., Studies of the pulmonary circulation in man at rest. Normal variations and the interrelations between increased pulmonary blood flow, elevated pulmonary arterial pressure and high pulmonary "capillary" pressures. J. Clin. Invest., 1950, 29, 602.

12. Lilienthal, J. L., Jr., Riley, R. L., Proemmel, D. D., and Franke, R. E., An experimental analysis in man of the oxygen pressure gradient from alveolar air to arterial blood during rest and exercise at sea level and at altitude. Am. J. Physiol., 1946, 147, 199.

13. Riley, R. L., and Cournand, A., Analysis of factors affecting partial pressures of oxygen and carbon dioxide in the gas and blood of the lungs: Theory. J. App. Physiol., 1951, 4, 77.

14. Riley, R. L., Cournand, A., and Donald, K. W., Analysis of factors affecting partial pressures of oxygen and carbon dioxide in gas and blood of the lungs: Methods. Ibid., 102.

15. Donald, K., Renzetti, A., Riley, R. L., and Cournand, A., Analysis of factors affecting the concentrations of oxygen and carbon dioxide in gas and blood of lungs: Results in patients with pulmonary disease. J. App. Physiol., 1952, 4, 497.

16. Shepard, R. H., Unpublished calculations.

17. Riley, R. L., Riley, M. C., and Hill, H. McD., Diffuse pulmonary sarcoidosis : diffusing capacity during exercise and other lung function studies in relation to ACTH therapy. Bull. Johns Hopkins Hospital, 1952, 91, 345.

18. Bahnson, H., Personal communication.

19. Cohen, G., Personal communication.

20. Andrus, E. C., Newman, E. V., Riley, R. L., Shulman, L. E., and Bahnson, H. T. The preoperative and postoperative management of some of the pulmonary complications of mitral stenosis. Tr. A. Am. Physicians, 1952, 65, 268.

21. Schaefer, K.-E., and Alvis, H. J., The effect of inhalation of low oxygen concentration $\left(10.5 \% \mathrm{O}_{2}\right.$ in $\mathrm{N}_{2}$ ) over a period of 33 minutes on respiration, pulse rate, arterial oxygen saturation (oximeter) and oxygen uptake. Med. Res. Lab. Report No. $175 \mathrm{Bu}$ Med. Project N M 002 015.03.02, U. S. Naval Submarine Base, New London, 1951, 10, 76.

22. Fishman, A. P., McClement, J., Himmelstein, A., and Cournand, A., Effects of acute anoxia on the circulation and respiration in patients with chronic pulmonary disease studied during the "steady state." J. Clin. Invest., 1952, 31, 770.

23. Riley, R. L., Shepard, R. H., Cohn, J. E., Carroll, D. G., Armstrong, B. W., The maximal diffusing capacity of the lungs. In preparation.

24. Austrian, R., McClement, J. H., Renzetti, A. D., Jr., Donald, K. W., Riley, R. L., and Cournand, A., Clinical and physiological features of some types of pulmonary diseases with impairment of alveolarcapillary diffusion. The syndrome of alveolarcapillary block. Am. J. Med., 1951, 11, 667.

25. Short, D. S., A survey of pulmonary embolism in a general hospital. Brit. Med. J., No. 4762, 790, April 12, 1952.

26. Burton, A. C., On the physical equilibrium of small blood vessels. Am. J. Physiol., 1951, 164, 319.

27. Nichols, J., Girling, F., Jerrard, W., Claxton, E. B., and Burton, A. C., Fundamental instability of the small blood vessels and critical closing pressures in vascular beds. Am. J. Physiol., 1951, 164, 330.

28. Blount, S. G., Jr., McCord, M. C., and Anderson, L. L., The alveolar-arterial oxygen pressure gradient in mitral stenosis. J. Clin. Invest., 1952, 31, 840. 